\title{
Do carbon emissions accelerate low-carbon innovation? Evidence from 285 Chinese prefecture-level cities
}

\author{
An Pan $^{1}$ (D) Wenna Zhang ${ }^{1} \cdot{\text { Qizhuo } \mathrm{Xie}^{2} \cdot \text { Ling Dai }^{3} \cdot \text { Yunyi Zhang }}^{4}$ \\ Received: 20 March 2021 / Accepted: 3 May 2021 / Published online: 7 May 2021 \\ (C) The Author(s), under exclusive licence to Springer-Verlag GmbH Germany, part of Springer Nature 2021
}

\begin{abstract}
Climate change caused by carbon emissions has a strong influence on the economy and human society. Though numerous previous studies have emphasized the importance of low-carbon innovation on curbing or mitigating carbon emissions, not much attention has been given to the reverse effect. We used a panel of 285 Chinese prefecture-level cities from 2005 to 2016 and Cooperative Patent Classification (CPC)-Y02 patents as low-carbon innovation indicators. The results show that the increasing carbon emissions accelerate cities' low-carbon innovation in China, and the predicted effect varies across low-carbon innovation types. As carbon emissions rise, more low-carbon innovation will occur in activities with higher carbon emissions. Besides, we explore environmental awareness as the mediation channel for carbon emissions to impact low-carbon innovation. With the help of media, government, and enterprises, the growing carbon emissions promote public environmental awareness and change consumers' behaviors, motivating companies to speed up low-carbon innovation.
\end{abstract}

Keywords Climate change $\cdot$ Low-carbon innovation $\cdot \mathrm{CPC}-\mathrm{Y} 02$ patents $\cdot$ Environmental awareness $\cdot$ Mediation

\section{Introduction}

In the 2015 Paris Agreement, 195 countries pledged to limit the rise in global temperature to $1.5-2^{\circ} \mathrm{C}$. However, not much success has been achieved, currently setting us on a path to $3^{\circ} \mathrm{C}$ global warming. The past decade has seen more threats caused by global warming-storms, floods, heatwaves, droughts, melting glaciers, wildfires, and reducing runoff (Zhang et al. 2018; IPCC 2019; Mohanty and Maiti 2021). Research shows that extreme weather and wildfires directly or indirectly affect the economic sectors (Sieg et al. 2019), and

Responsible Editor: Roula Inglesi-Lotz

An Pan

panan0819@zuel.edu.cn

1 School of Economics, Zhongnan University of Economics and Law, Wuhan 430073, Hubei, People's Republic of China

2 School of Management, Fudan University, Shanghai 200433, People's Republic of China

3 School of Economics, Zhejiang University, Hangzhou 310058 Zhejiang, People's Republic of China

4 Cornell Institute for Public Affairs, Cornell University, Ithaca, NY 14850, USA sea-level rise puts low-lying coastal areas at high risk (Hauer et al. 2016). It has also been proven that a $3{ }^{\circ} \mathrm{C}$ air temperature increase could reduce annual runoff at a rate of around 3\% precipitation decrease, which exacerbating water resource scarcity (Mastrotheodoros et al. 2020). Climate change emergency requires us to increase and speed up climate change mitigation and adaptation efforts until carbon neutrality is reached.

As a major carbon emitter, China is pursuing low-carbon innovation to curb the problem. On the one hand, China's greenhouse gas (GHG) emissions account for more than a quarter of global emissions, and Chinese per capita emissions are about 40\% higher than the global average (UNEP 2020). On the other hand, China's low-carbon innovation patents numbers, policies to promote renewable energy, and subsidies to support wind and solar power generation appear at the top of the global rankings (Deloitte 2018; WIPO 2020). It implies that there may be a relationship between China's increasing carbon emissions and low-carbon innovation. Departing from the previous studies emphasizing the impact of low-carbon innovation on reducing carbon emissions, this paper focuses on the reverse effect.

We used a panel dataset of 285 Chinese prefecture-level cities from 2005 to 2016 to explore whether the increasing carbon emissions accelerate cities' low-carbon innovation 
and the possible mediation mechanism. This research has three main novelties: (1) Though Su and Moaniba (2017) and Wang et al. (2020) have suggested that low-carbon innovation responds to climate change positively, they provided evidence only from the national and provincial levels. As cities become more important in mitigating carbon emissions and promoting low-carbon innovation, more empirical evidence from the city level is needed, and our samples help fill this gap. (2) The heterogeneity of low-carbon innovation types within the impact mechanism is considered in this study. The empirical results show that low-carbon innovation occurs more frequently in areas with higher carbon emissions. (3) To further explore the mechanism, we test the mediating role of growing environmental awareness. First, information on carbon emissions and their hazards is transmitted to the public through social media. In this process, public environmental awareness continues to grow, causing a change in people's behaviors. More consumers prefer low-carbon productions and start to pay attention to companies' low-carbon responsibilities, leading to companies' engagement in promoting cities' low-carbon innovation. These findings can lead to evidence-informed policies in mitigating the impact of climate change associated with carbon emissions.

The rest of the research arrangements are as follows: The "Literature review and research hypotheses" presents the literature review and puts forward research hypotheses. The "Methodology and data" section introduces the methodology and data. The "Empirical results and robust test" section reports the empirical results and robust analysis. The "Discussion" section sheds light on the discussion of the results, and the "Conclusions and policy implications" section provides conclusions and policy implications.

\section{Literature review and research hypotheses}

\section{Carbon emissions and low-carbon innovation}

Since the industrial revolution, global carbon emissions grew dramatically. Many studies show that low-carbon innovation is essential to reduce carbon emissions (Zhang et al. 2017) and contributes in four ways: (1) Improve fossil fuel utilization efficiency and reduce carbon emissions that come from fossil fuel combustion. As for fossil fuel, innovation includes more effective combustion methods and efficient internal combustion engines (Wilson et al. 2019). As for secondary energy derived from fossil fuel, the innovation focuses on reducing the communication network's energy consumption (Jenkins and Hopkins 2019) and creating more energy-efficient home appliances (Huo et al. 2020). (2) Look for alternatives to fossil fuels, known as cleaner energy sources, such as solar, wind, or geothermal energy (Polzin 2017). The innovation in this field help applies renewable energy to electricity generation
(Jenkins and Hopkins 2019), photovoltaic cell roof systems, and geothermal heating systems (Wilson 2018). (3) Improve industrial processes or equipment with excessive carbon emissions. For example, the new widely used heat circulation systems in the sector of the manufacture emit less $\mathrm{CO}_{2}$ compared to the traditional ones (Jenkins and Hopkins 2019), and the mineral components (MIC) used in cement production considerably lower the cement industry carbon emission intensity (Kajaste and Hurme 2016). (4) Capture, store, sequestration, and disposal of $\mathrm{CO}_{2}$ (Hasan et al. 2015). The innovation could prevent carbon emissions from leaking into the atmosphere and is seen to be promising in the future, as it means we can curb carbon emissions while not limiting fossil fuel usage (Liu and Liang 2011). However, this technology is not widely available now due to the lack of incentives for stakeholders and development difficulty (Von Hirschhausen et al. 2012).

As mentioned above, China's low-carbon innovation is especially active in the past few decades (Yang and Liu 2020). However, its carbon emissions are still growing. As shown in Fig. 1, China's carbon emissions and low-carbon innovation share the same growth trend. This phenomenon can be explained by previous research focusing on economic growth and carbon emissions: in the short term, the economic growth and carbon emissions have Granger causality (Esso and Keho 2016). As China's economy is growing steadily even during the COVID-19 pandemic, its carbon emissions are predicted to rise continuously in the near future. This means that China has to accelerate domestic low-carbon innovation to realize the promise of striving to peak carbon emissions by 2030 and achieving carbon neutrality around 2060 . We wonder whether the pressure of carbon emissions mitigation stimulates low-carbon innovation. Su and Moaniba (2017) were the first to study the carbon emissions and lowcarbon innovation linkage. They used a panel dataset of 70 countries to conduct empirical tests, and the results showed that countries' low-carbon innovation actively responded to climate change caused by fossil energy usage. Wang et al. (2018) extended the econometric model to a spatial one and used a Chinese provincial-level dataset to provide evidence. Lin and Zhu (2019) argued that climate change has an impact on energy-related innovation while controlling energy prices, R\&D, and other factors. The results were also based on Chinese provincial-level data. Wang et al. (2020) further investigated the influence mechanism and found that environmental regulations play an essential mediation role between climate change and low-carbon innovation.

From the aspect of cities, statistics from UN-Habitat show that urban areas consume $78 \%$ of the world's energy and contribute more than $60 \%$ of GHG emissions. At the 2014 United Nations Climate Summit, more than 2000 cities worldwide participated in the global Compact of Mayors to reduce GHG emissions. The contract includes establishing a city climate data platform and the provision of standardized reports 
Fig. 1 China's $\mathrm{CO}_{2}$ emissions and real GDP (constant 2010) from 2005 to 2016. The data comes from the World Bank

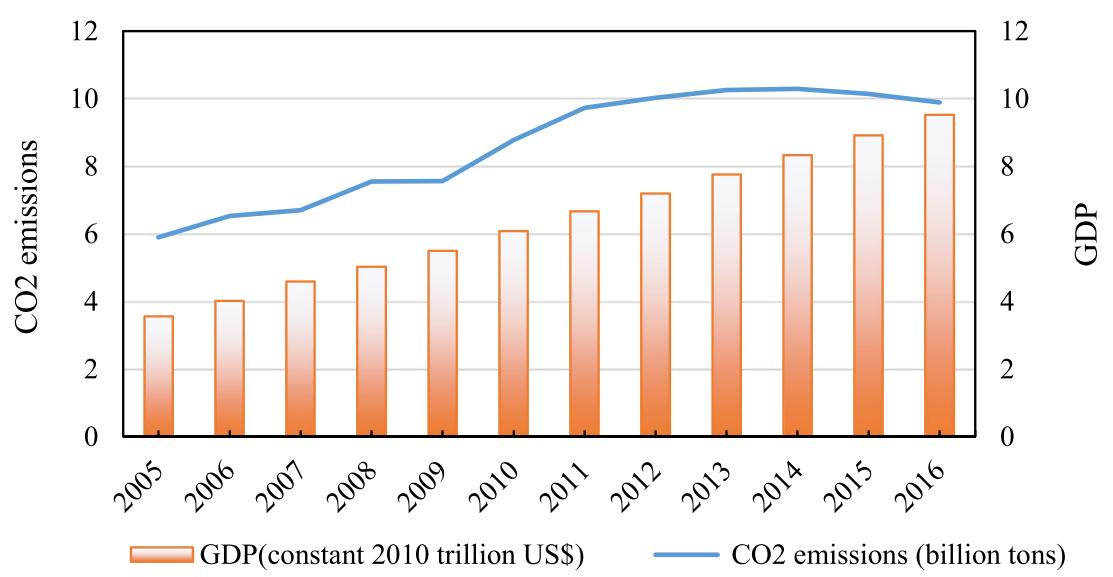

facilitating data-based analysis. It demonstrates that cities can provide unique support for low-carbon transitions and become essential units for controlling climate change (Bastin et al. 2019). Because of differences in scale, resources, and development levels, cities may take contrasting low-carbon policies even compared with those in the same province (Price et al. 2016). The combination of low-carbon policies and their implementation is vital for companies to determine their lowcarbon innovation expenditure plans (Lo 2014; Rogge and Schleich 2018). For these reasons, studies start to focus on innovative activities from the city level (Vallance et al. 2020; Song et al. 2020).

In conclusion, with the pressure of carbon emissions mitigation, cities - the principal emitters and innovation contributors - may accelerate low-carbon innovation. Therefore, we propose the following hypothesis:

Hypothesis 1: Carbon emissions can accelerate lowcarbon innovation in cities.

\section{Heterogeneity in low-carbon innovation types}

Scholars focusing on low-carbon innovation tend to study the heterogeneity in low-carbon innovation types to further their study. Albino et al. (2014) subdivided low-carbon energy innovation into three types, nuclear power generation, alternative energy production, and energy conservation, and found that the promotion of government strategy and business activities to different types of low-carbon energy innovation is different. Wang et al. (2020) demonstrated the heterogeneity of environmental regulation in stimulating low-carbon innovation by studying the clean and the gray low-carbon innovation types. Malhotra and Schmidt (2020) classified lowcarbon technology into three types based on the two dimensions: need for customization and degree of design complexity and augured that the dependence on market capacity and national industrial policy varied across low-carbon innovation types. These studies suggest that focusing on the types of low-carbon innovation helps further reveal the heterogeneity in the connections between factors and provides richer evidence for policy.

In order to further investigate the heterogeneity related to low-carbon innovation types, we classified our patent sample according to the Cooperative Patent Classification (CPC). The carbon emissions mitigation technologies can be divided into seven schemes: Y02B, Y02C, Y02D, Y02E, Y02P, Y02T, and $\mathrm{Y} 02 \mathrm{~W}$. Appendix A Table 8 provides more details for each scheme. With the classification standard, China's lowcarbon patents from 2005 to 2016 are sorted and shown in Fig. 2. We find that $\mathrm{Y} 02 \mathrm{E}$ and $\mathrm{Y} 02 \mathrm{P}$ have the highest number of patents. Y02E refers to patents reducing GHG emissions related to energy generation, transmission, or distribution. Y02P refers to climate change mitigation technologies in the production or processing of goods. In fact, if we break down carbon emissions by the economic activities that lead to their production, we will find that the energy and production sectors are also the ones with the highest carbon emissions. Because of the high consumption of coal, natural gas, and oil, electricity and heat production account for about $25 \%$ of the total emissions. Industry accounts for about $21 \%$ of the total. In addition to consuming fossil fuels, industrial processes such as chemical, metallurgical, and mineral conversion also contribute a lot to carbon emissions. According to the data from EPA (US Environmental Protection Agency), transportation accounts for about $14 \%$ (mostly from petroleum-based fuels), and buildings account for about $6 \%$ (including home heating). This shows that the areas with higher carbon emissions are also the ones with more active low-carbon innovation.

Therefore, we assume that the increasing carbon emissions helps realize this process. That is, the promoting effect of carbon emissions on low-carbon innovation has the heterogeneity on the types of low-carbon innovation. Previous literature has focused on the human factors that facilitate low-carbon innovation, such as R\&D investment (Mennicken et al. 2016; Paramati et al. 2020), foreign direct investment (Luo et al. 2020), informatization (Batool et al. 2019), openness (Gosens 2020), and economic development (Shi et al. 2021). It contributes to 
Fig. 2 The number of different low-carbon innovation types in China from 2005 to 2016. Data from incoPat Global Patent Database. https://www.incopat. $\mathrm{com} /$

\section{0}

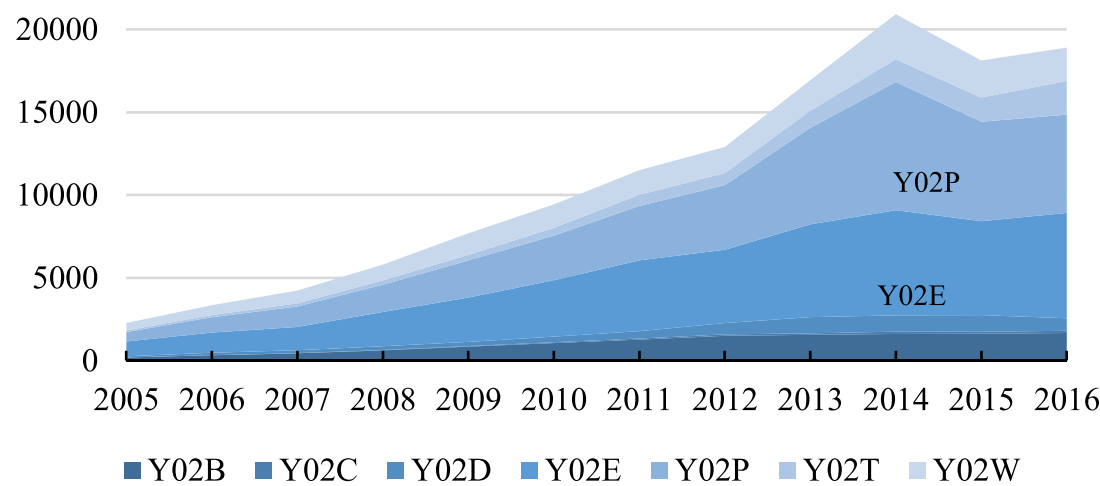

the explanation of how low-carbon innovation occurs, but it fails to explain the imbalance in different low-carbon innovation types' development. Focusing on the performance of carbon emissions helps us explain this phenomenon. Thus, we propose Hypothesis 2.

Hypothesis 2: There is heterogeneity in the promoting effects of carbon emissions on different low-carbon innovations. The increasing carbon emissions lead to the surge of lowcarbon innovations to activities with higher carbon emissions.

\section{Environmental awareness as the mediator}

Studies have shown that the increase in carbon emissions has aroused widespread concern from all society sectors (Leonidou and Leonidou 2011). Media, government, and enterprises play a vital role in this process (Murray and Mills 2011; Motoshita et al. 2015; Ohler et al. 2020). The growing environmental awareness promotes low-carbon innovation in two ways. First, consumers' concern about the environment affects their choice of environmentally friendly products (Loureiro and Lotade 2005). Due to ethics and social responsibility, people's consumption behaviors can be affected by convenience, price, and trade-offs. Considerations are usually made between product range and greenness (Akhtar et al. 2020). The public with environmental consciousness tends to buy lower carbon products, and this kind of group taking low-carbon consumption actions are expanding (Motoshita et al. 2015). In order to sell more products, companies tend to take low-carbon products into consideration and search for low-carbon innovation. Second, as the carbon information disclosure is gradually developing over the world, the increase in public environmental awareness will trigger more attention to corporate environmental responsibilities. It forces companies to reflect on their carbon emissions behaviors and take innovative activities for their corporate images (Du et al. 2019). Retailers and manufacturers with excellent environmental protection capabilities have benefited from the increase of public environmental awareness (Soytas and Sari 2009), and the improvement of their company performance is believed to be related to their environmental innovation (Sarfraz et al. 2020). It will drive more corporations to get involved in low-carbon innovation and sustainable development.

In conclusion, with the help of media, government, and enterprises, public environmental awareness grows gradually and then changes the consumers' behaviors. People tend to accept low-carbon consumption and pay more attention to enterprises' low-carbon responsibility. Stimulated by the transition, more enterprises make low-carbon innovation to improve their products or services. Therefore, we propose the following hypothesis that requires testing:

Hypothesis 3: Environmental awareness is a mediator of carbon emissions' impact on low-carbon innovation.

\section{Methodology and data}

The verification is divided into three stages. In the first stage, hypothesis 1 will be tested to verify whether the increasing carbon emissions will boost low-carbon innovation. Hypothesis 2 will be tested in the second stage to verify whether the response of different low-carbon innovation types to carbon emissions has heterogeneity. Besides, the stage will also check whether activities with higher carbon emissions can attract more low-carbon innovation when carbon emissions increase. Finally, hypothesis 3 will be tested to verify whether environmental awareness is a significant mediation channel for the impact of carbon emissions on low-carbon innovation.

\section{Model constructing}

The benchmark model is constructed to test hypothesis 1:

$Y 02_{i t}=\alpha_{0}+\beta_{1} C O_{2 i, t-1}+\beta_{2} X_{i t}+\lambda_{i}+\gamma_{t}+\varepsilon_{i t}$

where $\mathrm{i}$ refers to the observation city and $\mathrm{t}$ refers to the observation year. $\mathrm{YO} 2$ is the degree of low-carbon innovation; $\mathrm{CO}_{2}$ 
is carbon emissions, the variable of interest. It is known that carbon emissions are difficult to be directly perceived, and people cannot react to their changes unless the information of emissions is released by the government or organizations. Thus, we used the first-order lag term of $\mathrm{CO}_{2}$ as the core explanatory variable as carbon emission data publication often has a lag period of 1 year. $X$ are control variables, including research and development $(R D)$, foreign direct investment $(F D I)$, Internet users (INT), opening degree $(O P E N)$, and gross domestic product per capita $(P G D P) . \lambda_{i}$ is the cityfixed effect, $\gamma_{t}$ is the year-fixed effect, and $\varepsilon_{i t}$ is the error term.

To verify hypothesis 2 , we regress different types of lowcarbon innovation on $\mathrm{CO}_{2}$ emissions. Furthermore, to test hypothesis 3 , we used the mediation models created by Baron and David (1986). The method has been widely used to test the mediation effect and its style in environmental research (Chang 2011). Equations (2) (4) describe the three steps.

$$
\begin{aligned}
& Y=c X+e_{i} \\
& M=a X+e_{i} \\
& Y=c^{\prime} X+b M+e_{i}
\end{aligned}
$$

Followed this method, Eq. (5) Eq. (6) are constructed.

$$
\begin{aligned}
& E A_{i t}=\alpha_{1}+\beta_{3} C O_{2 i, t-1}+\beta_{4} X_{i t}+\lambda_{i}+\gamma_{t}+\varepsilon_{i t} \\
& Y 02_{i t}=\alpha_{2}+\beta_{5} C O_{2 i, t-1}+\beta_{6} E A_{i t}+\beta_{7} X_{i t}+\lambda_{i}+\gamma_{t}+\varepsilon_{i t}
\end{aligned}
$$

$E A$ refers to environmental awareness, which is the mediation channel of interest. The mechanism diagram is shown in Fig. 3 (Baron and David 1986).

\section{Variable selection and data description}

This study uses a panel dataset of 285 Chinese prefecturelevel cities from 2005 to 2016.
$Y 02$ is the number of low-carbon innovation patents, using as the indicator of cities' degree of low-carbon innovation in the observed years. Generally, a region's degree of lowcarbon innovation can be represented by the number of patents (Haščič and Migotto 2015). To differentiate the types of low-carbon innovation, we use the CPC developing by the European Patent Office and the US Patent and Trademark Office. The scheme Y02 marks patents of low-carbon innovation, making it possible for us to distinguish low-carbon innovation from others. Besides, we only sum up the invention patents issued to applicants and drop the invention patents that have not been issued, utility models patents, and design patents. It is believed that the invention patents issued to applicants are more innovative than other types of patents ( $\mathrm{Su}$ and Moaniba 2017) and can reflect the degree of innovation in a region more accurately. Y02 scheme notes technologies or applications for mitigation or adaptation against climate change, which has eight subclasses: Y02A, Y02B, Y02C, Y02D, Y02E, Y02P, Y02T, and Y02W. As Y02A spots the technologies of climate change adaptation, we drop it when calculating. As seen in Fig. 4, the distribution of low-carbon innovation in China is not even. Cities along the east coast have a higher level of low-carbon innovation than those in the west's inland cities. Beijing, Shanghai, Shenzhen, and Nanjing rank top 4 in the degree of low-carbon innovation. These cities also rank high in carbon emissions (top 10\%).

$\mathrm{CO}_{2}$ is used to measure carbon emissions. Karoline et al. (2017) argued that most of the carbon emissions of cities come from energy consumption. Therefore, we use energy consumption to estimate cities' carbon emissions. There are 28 common energy forms: row coal, washed coal, other washed coal, briquette, coal gangue, coke, coke oven gas, blast furnace gas, converter gas, other gas, other coking products, crude oil, gasoline, kerosene, diesel oil, fuel oil, naphtha, lubricating oil, paraffin, solvent naphtha, petroleum asphalt, petroleum coke, liquefied petroleum gas, refinery dry gas, other oil products, natural gas, liquefied natural gas, and other

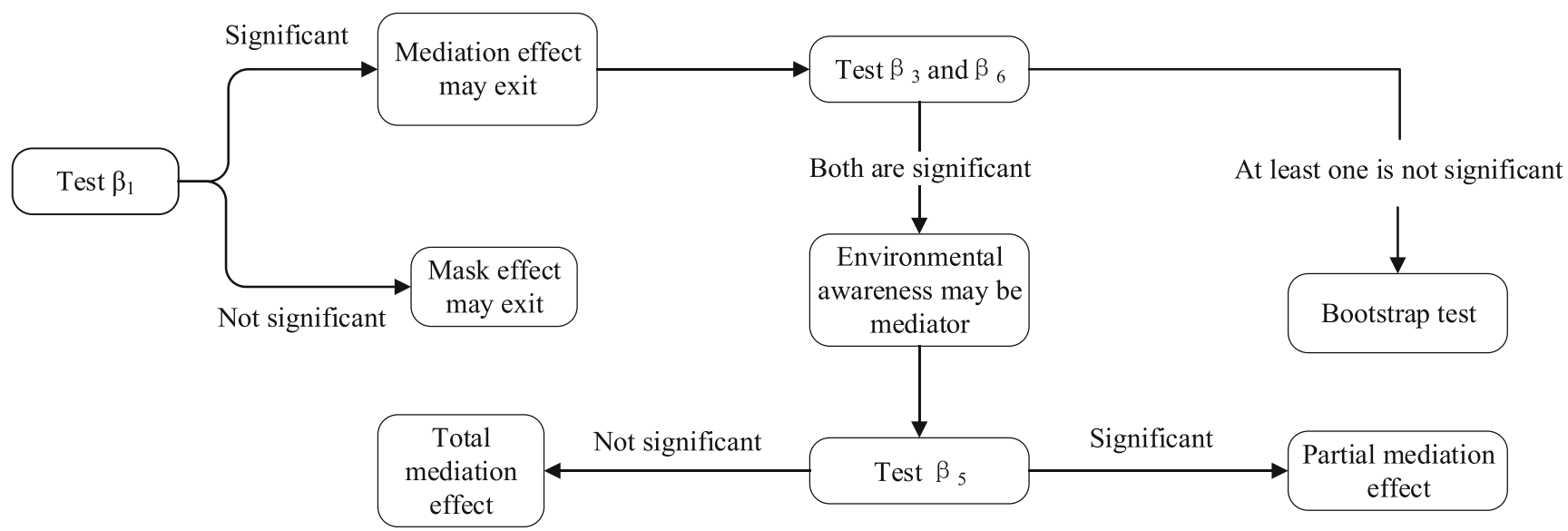

Fig. 3 Testing procedures of the mediation effect 
Fig. 4 Cities' average number of Y02 patents during the observation period. The darker the blue color, the more lowcarbon patents the city has

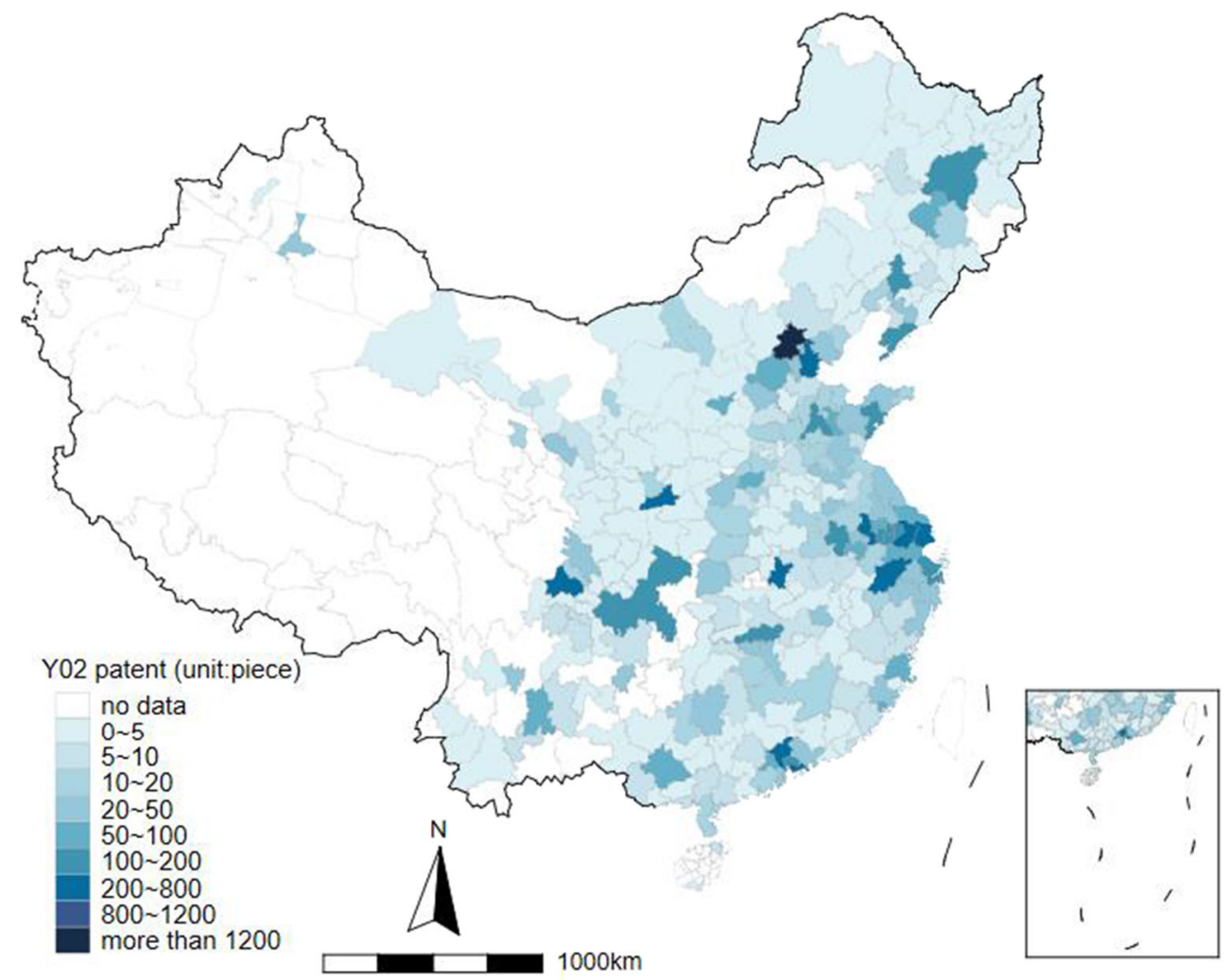

energy forms. As the city database only provides very few energy types' consumption data, using that database would underestimate the carbon emissions. Thus, we use a decomposition method based on the assumption that a province's cities have the same energy intensity (Dhakal 2009) and the argument that energy consumption is strongly correlated with GDP (Rahman et al. 2020). Similar methods are used in situations where direct data is difficult to obtain (Le Quéré et al. 2020). The steps are as follows.

First, we use provincial-level data provided the consumption of the 28 common energy forms. Then, we calculate the proportion of each city's GDP in its province GDP to get the energy decomposition coefficient. Based on it, each city's energy consumption equals multiplying its province's energy consumption by the corresponding energy decomposition coefficient. At last, a carbon emissions estimation method offered by IPCC is used to do the final calculation. The following formula summarizes the calculation process:

$C O_{2 i}=\sum_{i=1}^{28} E C_{i} \times \delta_{i} \times E F_{i} \times \theta_{i} \times \frac{44}{12}$

where $\mathrm{CO}_{2 i}$ are the $\mathrm{CO}_{2}$ emissions of city i, $E C_{i}$ is the energy consumption of city $\mathrm{i}, \delta_{i}$ is the average low calorific value of energy $\mathrm{i}, E F_{i}$ is the carbon emission factor of energy $\mathrm{i}$, and $\theta_{i}$ is the carbon oxidation rate. See Appendix A Table 9 for the average low calorific values, carbon emission factors, and carbon oxidation rates of the 28 energy forms. As shown in Fig. 5, there is a positive correlation between carbon emissions and low-carbon innovation.

$E A$ is to describe environmental awareness. This study uses the degree of education as a proxy of environmental awareness. It is shown that citizens with higher education levels tend to have a higher degree of environmental awareness (Liu et al. 2020). The proxy is measured by the number of college students per 10,000 citizens.

A series of variables that may influence low-carbon innovation are controlled to eliminate omitting variables bias. These variables include the following: (1) $R D$ describes the level of R\&D expenditure. Due to the lack of enterprises' $\mathrm{R} \& \mathrm{D}$ data, the government's scientific expenditure is adopted as an alternative proxy. (2) FDI refers to the level of foreign investment. The number of newly signed projects of FDI is chosen as the alternative proxy because compared with FDI flows, it will not ignore the potential of small projects in technology transfer, which needs to be controlled. (3) INT describes the level of information development using the number of Internet users as a proxy. It is added because cities with higher information levels are proved to have stronger innovation vitality (Xu et al. 2019). (4) OPEN refers to the degree of opening. The ratio of the city's export volumes to its GDP is used as the proxy. The export volumes are converted into $\mathrm{RMB}$ at the closing rate of each year. (5) $P G D P$ refers to GDP per capita. 
Fig. 5 Scatter distribution and linear fitting of carbon emissions and low-carbon innovation

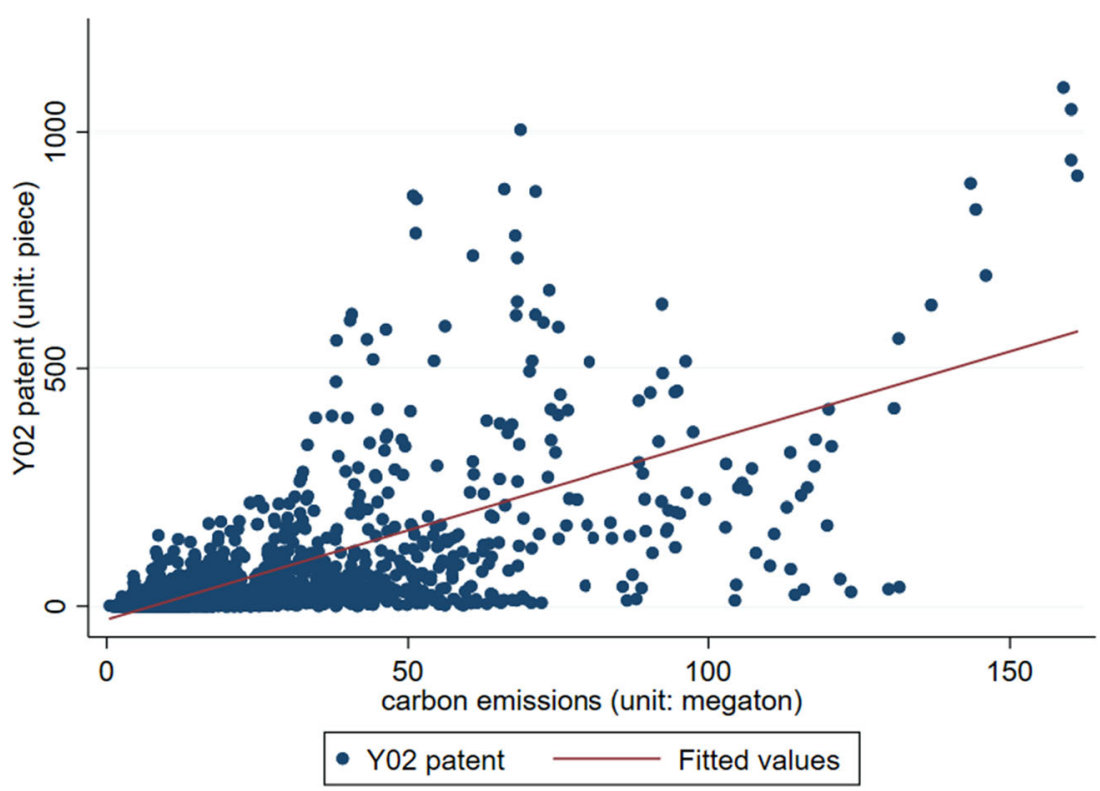

The number of invention patents issued to applicants comes from incoPat Global Patent Database. This database covers more than 100 million patent documents in 120 countries, organizations, or regions around the world and has been used by researchers in various fields (Chen et al. 2020). The energy consumption data comes from the "China Energy Statistical Yearbook." Each city's GDP, scientific expenditure, number of newly signed projects of FDI, Internet users, export volume, GDP per capita, number of college students, and total population come from the "China City Statistical Yearbook." Provincial GDP comes from the "China Statistical Yearbook." Descriptive statistics of the variables are shown in Table 1.
Table 2 lists the Pearson correlation coefficients and the variance inflation factors of variables. The VIF indicates that there is no multicollinearity problem in the benchmark model.

\section{Empirical results and robust test}

\section{Results for benchmark model}

Regression is performed according to Eq. (1) to test hypothesis 1. Regression (1) in column (1) of Table 3 reported a positive $\mathrm{CO}_{2}$ coefficient. It suggests that hypothesis 1 is confirmed: cities' increased carbon emissions lead to accelerated low-carbon innovation. For control
Table 1 Summary statistics for variables

\begin{tabular}{llllllll}
\hline Variable & Unit & Observations & Mean & Sd & Min & Med & Max \\
\hline Y02 & Piece & 3420 & 35.90 & 138.00 & 0 & 4 & 3063 \\
$\mathrm{CO}_{2}$ & Megaton & 3418 & 17.10 & 19.30 & 0.54 & 10.80 & 161.00 \\
RD & Billion Yuan & 3419 & 5.42 & 20.80 & 0.00 & 1.21 & 404.00 \\
FDI & One hundred pieces & 3194 & 1.19 & 3.90 & 0.01 & 0.20 & 60.10 \\
INT & One million households & 3402 & 0.59 & 1.33 & 0.00 & 0.29 & 51.70 \\
OPEN & \% & 3144 & 0.13 & 0.24 & 0.00 & 0.05 & 6.51 \\
PGDP & Ten thousand Yuan per person & 3415 & 3.59 & 2.95 & 0.01 & 2.77 & 46.80 \\
Y02B & Piece & 3420 & 3.72 & 14.60 & 0 & 0 & 197 \\
Y02C & Piece & 3420 & 0.22 & 1.27 & 0 & 0 & 22 \\
Y02D & Piece & 3420 & 1.78 & 13.10 & 0 & 0 & 287 \\
Y02E & Piece & 3420 & 13.00 & 52.60 & 0 & 1 & 1175 \\
Y02P & Piece & 3420 & 12.30 & 47.20 & 0 & 2 & 1175 \\
Y02T & Piece & 3420 & 2.57 & 11.40 & 0 & 0 & 284 \\
Y02W & Piece & 3420 & 5.08 & 16.00 & 0 & 1 & 284 \\
\hline
\end{tabular}


Table 2 Pearson correlation matrix

$\begin{array}{lllllllll}\text { Variable } & \mathrm{Y} 02 & \mathrm{CO}_{2} & \mathrm{EA} & \mathrm{RD} & \mathrm{FDI} & \mathrm{INT} & \mathrm{OPEN} & \mathrm{VIF}\end{array}$

Y02 1

$\begin{array}{lll}\mathrm{CO}_{2} & 0.54 \quad 1\end{array}$

$\begin{array}{llll}\text { EA } & 0.25 & 0.36 & 1\end{array}$

$\begin{array}{lllll}\mathrm{RD} & 0.84 & 0.58 & 0.14 & 1\end{array}$

FDI $\quad \begin{array}{llllll}0.55 & 0.52 & 0.08 & 0.69 & 1\end{array}$

INT $\quad \begin{array}{lllllll}0.52 & 0.60 & 0.20 & 0.59 & 0.54 & 1\end{array}$

$\begin{array}{llllllll}\text { OPEN } & 0.26 & 0.20 & 0.02 & 0.28 & 0.49 & 0.24 & 1\end{array}$

variables, the coefficient of $R D$ is positive and significant, indicating that $\mathrm{R} \& \mathrm{D}$ expenditure has a promoting effect on low-carbon innovation. The coefficients of FDI and $O P E N$ are significantly negative, indicating that foreign direct investment and opening restrain domestic lowcarbon innovation. For foreign direct investment, this may be due to the crowding-out effect. With the investment flowing in, it becomes easier to introduce foreign low-carbon technologies and inhibits domestic R\&D of low-carbon innovation. And with a higher degree of openness, the market competition may be intensified, making companies pay more attention to short-term interests and do not have enough resources to invest in activities with longer investment return cycles, for example, low-carbon research and development. It reduces the overall lowcarbon innovation level of the city. Besides, the coefficients of INT and PGDP are not significant, indicating that the current development level of information and economic development have no significant impact on lowcarbon innovation.

Further attention is paid to the heterogeneous impact of carbon emissions on different types of low-carbon innovation. Based on the benchmark model of Eq. (1), we regress $Y 02 B \sim Y 02 W$ as proxies of different types of low-carbon innovation on the core explanatory variables and control variables to verify hypothesis 2 . The regression results (2) to (8) are shown in columns (2) to (8) of Table 3. After other related variables are controlled, comparing the coefficients in each column, the coefficients of $\mathrm{CO}_{2}$ are all positive and significant at the $1 \%$ level, indicating that cities' increased carbon emissions can promote all types of low-carbon innovation, which helps verify hypothesis 1 .

The t-statistic in parenthesis. ***,**, and * indicate statistically significant at $1 \%, 5 \%$, and $10 \%$, respectively

Besides, the different coefficients of $\mathrm{CO}_{2}$ reveal the heterogeneity in the impact of carbon-emissions on different types of low-carbon innovation. The coefficients related to Y02E and Y02P are larger than those of the other Y02 types. It indicates that low-carbon innovation in higher carbon emissions sectors is more likely to be driven by the increasing carbon emissions. Hypothesis 2 holds.

\section{Results for mediation test}

Based on the above results, hypothesis 3 is tested according to the causal steps approach. Because hypothesis 1 holds, the

Table 3 Results for regressing different types of Y02 on independent variables based on the benchmark model

\begin{tabular}{|c|c|c|c|c|c|c|c|c|}
\hline & $\underline{(1)}$ & $(2)$ & (3) & (4) & $\underline{(5)}$ & $(6)$ & $(7)$ & $\underline{(8)}$ \\
\hline & Y02 & Y02B & $\mathrm{Y} 02 \mathrm{C}$ & Y02D & Y02E & $\mathrm{Y} 02 \mathrm{P}$ & Y02T & Y02W \\
\hline \multirow[t]{2}{*}{$\mathrm{CO}_{2}$} & $3.250 * * *$ & $0.280 * * *$ & $0.030 * * *$ & $0.282 * * *$ & $1.161 * * *$ & $1.206^{* * * *}$ & $0.251 * * *$ & $0.263 * * *$ \\
\hline & $(16.55)$ & $(8.49)$ & $(8.90)$ & $(8.12)$ & (14.17) & $(16.61)$ & $(10.40)$ & (9.14) \\
\hline \multirow[t]{2}{*}{$\mathrm{RD}$} & $1.373 * * *$ & $0.143 * * *$ & $0.012 * * *$ & 0.016 & $0.397 * * *$ & $0.481 * * *$ & $0.315 * * *$ & $0.113 * * *$ \\
\hline & (17.74) & $(11.00)$ & $(8.77)$ & (1.14) & $(12.31)$ & $(16.81)$ & $(33.11)$ & (9.99) \\
\hline \multirow[t]{2}{*}{ FDI } & $-2.795 * * *$ & $-0.643 * * *$ & $0.021 * * *$ & $-0.422 * * *$ & $-1.128 * * *$ & $-0.777 * * *$ & 0.080 & $-0.249 * * *$ \\
\hline & $(-6.05)$ & $(-8.31)$ & $(2.62)$ & $(-5.16)$ & $(-5.85)$ & $(-4.55)$ & $(1.41)$ & $(-3.68)$ \\
\hline \multirow[t]{2}{*}{ INT } & 0.344 & $0.564 * * *$ & $0.043 * * *$ & -0.097 & -0.078 & 0.149 & -0.111 & -0.040 \\
\hline & $(0.51)$ & $(5.02)$ & $(3.74)$ & $(-0.82)$ & $(-0.28)$ & $(0.60)$ & $(-1.35)$ & $(-0.41)$ \\
\hline \multirow[t]{2}{*}{ OPEN } & $-42.729 * * *$ & $-11.494 * * *$ & -0.128 & $-9.193 * * *$ & $-12.288 * * *$ & $-8.892 * *$ & -1.518 & $-3.637 * *$ \\
\hline & $(-3.86)$ & $(-6.19)$ & $(-0.67)$ & $(-4.69)$ & $(-2.66)$ & $(-2.17)$ & $(-1.12)$ & $(-2.24)$ \\
\hline \multirow[t]{2}{*}{ PGDP } & -0.216 & -0.015 & -0.012 & -0.028 & 0.084 & -0.248 & 0.053 & -0.085 \\
\hline & $(-0.39)$ & $(-0.16)$ & $(-1.28)$ & $(-0.29)$ & $(0.36)$ & $(-1.21)$ & $(0.78)$ & $(-1.05)$ \\
\hline Constant term & Yes & Yes & Yes & Yes & Yes & Yes & Yes & Yes \\
\hline City effect & Yes & Yes & Yes & Yes & Yes & Yes & Yes & Yes \\
\hline Year effect & Yes & Yes & Yes & Yes & Yes & Yes & Yes & Yes \\
\hline Observations & 2262 & 2262 & 2262 & 2262 & 2262 & 2262 & 2262 & 2262 \\
\hline
\end{tabular}


first step of the mediation test holds, and thus, only the second and third steps are examined below. Regressions (1) to (2) for mediation tests are reported in columns (1) to (2) in Table 4.

Columns (1) and (2) are the second and third steps of the mediation model. Columns (3) and (4) are the second and third steps in the robustness test for the mediation effect after changing the control variables. Columns (5) and (6) are the second and third steps in the robustness test for mediation effect after eliminating the extreme values. The t-statistic in parenthesis. $* * *, * *$, and $*$ indicate statistically significant at $1 \%, 5 \%$, and $10 \%$, respectively

Based on Eqs. (5) and (6), we examined hypothesis 3. Regression (1) corresponds to Eq. (5). The coefficient of $\mathrm{CO}_{2}$ is positive and significant at $1 \%$ level, which confirms a causal relationship between carbon emissions and environmental awareness: with an increase in the carbon emissions, there was also a rise in environmental awareness. In the second test step of the mediating effect, Regression (2) corresponds to Eq. (6). The coefficients of $\mathrm{CO}_{2}$ and $\mathrm{EA}$ are positive and significant at $5 \%$ and $1 \%$, and the coefficient of $\mathrm{CO}_{2}$ changed from 3.25 to 2.46 compared with column (1) in Table 3, passing the third test step of the mediation effect. All the regressions control the year effect and city effect.

Furthermore, the coefficient of $\mathrm{CO}_{2}$ in Regression (2) is statistically significant, which indicates that environmental awareness only plays a partial mediating role between carbon emissions and low-carbon innovation. Through regression results, we can calculate the total effect, direct effect, and indirect effect of carbon emissions on lowcarbon innovation: the total effect of carbon emissions on low-carbon innovation is 3.25 , which is significant; the direct effect of carbon emissions on low-carbon innovation is 2.46, which is significant but small; the indirect effect of carbon emissions on low-carbon innovation through environmental awareness is 0.82 ; the mediation effect accounted for $25 \%$ of the total effect, indicating that environmental awareness is a mediation channel for carbon emissions to promote low-carbon innovation; hypothesis 3 holds. Besides, after adding the mediation variable, we find that the sign and significance level of each control variable's coefficients in column (2) of Table 4 are consistent with the regression result of the benchmark model, indicating the above conclusions are robust.

\section{Robustness analysis}

In this study, we provide the robust tests by changing control variables and dropping extreme observations.

For the benchmark model, to avoid the impact of the specific measures of control variables on regressions, the robustness analysis is conducted by successively replacing each control variable's measures. Descriptive statistics of the alternative variables are reported in Table 5.
Table 4 Results for mediation test and its robust test

\begin{tabular}{|c|c|c|c|c|c|c|}
\hline & $\underline{(1)}$ & $\underline{(2)}$ & $\underline{(3)}$ & $\underline{(4)}$ & $\underline{(5)}$ & $\underline{(6)}$ \\
\hline & $\underline{\text { Step } 2}$ & Step3 & Step 2 & Step3 & $\underline{\text { Step } 2}$ & Step3 \\
\hline & EA & Y02 & EA & Y02 & EA & Y02 \\
\hline \multirow[t]{2}{*}{$\mathrm{CO}_{2}$} & $15.401 * * *$ & $2.457 * * *$ & $9.228 * * *$ & $1.226 * * *$ & $15.339 * * *$ & $2.459 * * *$ \\
\hline & (14.97) & (12.24) & (11.12) & $(4.89)$ & (13.48) & (11.11) \\
\hline \multirow[t]{2}{*}{ EA } & & $0.053 * * *$ & & $0.045 * * *$ & & $0.051 * * *$ \\
\hline & & (12.64) & & (7.16) & & (11.39) \\
\hline \multirow[t]{2}{*}{$\mathrm{RD}$} & -0.632 & $1.400 * * *$ & -0.379 & $3.481 * * *$ & -0.720 & $1.356^{* * * *}$ \\
\hline & $(-1.56)$ & (18.66) & $(-0.44)$ & (13.66) & $(-1.62)$ & $(16.50)$ \\
\hline \multirow[t]{2}{*}{ FDI } & 0.114 & $-2.783 * * *$ & $0.111 * * *$ & $-0.019 * *$ & 0.464 & $-2.710 * * *$ \\
\hline & $(0.05)$ & $(-6.22)$ & (3.39) & $(-1.97)$ & $(0.18)$ & $(-5.56)$ \\
\hline \multirow[t]{2}{*}{ INT } & 0.651 & 0.283 & $0.011 * * *$ & $0.009 * * *$ & 0.243 & 0.184 \\
\hline & $(0.19)$ & $(0.44)$ & $(4.59)$ & (12.93) & $(0.06)$ & $(0.26)$ \\
\hline \multirow[t]{2}{*}{ OPEN } & 72.116 & $-46.072 * * *$ & -0.002 & -0.001 & 86.820 & $-56.424 * * *$ \\
\hline & $(1.23)$ & $(-4.25)$ & $(-0.64)$ & $(-1.12)$ & $(1.24)$ & $(-4.38)$ \\
\hline \multirow[t]{2}{*}{ PGDP } & 0.690 & -0.261 & $0.028 * *$ & $0.046^{* * * *}$ & 0.492 & -0.239 \\
\hline & $(0.24)$ & $(-0.49)$ & $(2.36)$ & (13.00) & $(0.15)$ & $(-0.40)$ \\
\hline Constant term & Yes & Yes & Yes & Yes & Yes & Yes \\
\hline City effect & Yes & Yes & Yes & Yes & Yes & Yes \\
\hline Year effect & Yes & Yes & Yes & Yes & Yes & Yes \\
\hline Observations & 2235 & 2235 & 2430 & 2430 & 1932 & 1932 \\
\hline
\end{tabular}


Table 5 Summary statistics for alternative variables

\begin{tabular}{|c|c|c|c|c|c|c|c|}
\hline Variable & Unit & Observations & Mean & $\mathrm{Sd}$ & Min & Med & Max \\
\hline \#RD & $\%$ & 3418 & 4.33 & 9.54 & 0.03 & 1.68 & 132.54 \\
\hline \#FDI & $\%$ & 3253 & 202.10 & 199.65 & 0.13 & 136.01 & 1402.77 \\
\hline \#INT & Household per ten thousand persons & 3402 & 1310.52 & 1645.09 & 0.60 & 888.61 & 36634.76 \\
\hline \#OPEN & One hundred million Yuan & 3146 & 370.49 & 1328.99 & 0.00 & 41.66 & 18638.34 \\
\hline \#PGDP & Yuan & 3017 & 18025.38 & 7386.81 & 4987.00 & 17012.00 & 50940.72 \\
\hline
\end{tabular}

The t-statistic in parenthesis. *** indicates statistically significant at $1 \%$

The Regressions (1) to (6) are reported in columns (1) to (6) in Table 6. Regression (1) changed the measure of $R D$ from government science expenditure to the ratio of government science expenditure to GDP; Regression (2) changed the measure of $F D I$ from the number of newly signed FDI projects to the proportion of actual utilized foreign capital in GDP, and the actual utilized foreign capital is converted into RMB at the closing rate of each year; Regression (3) changed the measure of INT from the number of Internet users to the proportion of Internet users in the population of the city; Regression (4) changed the measure of OPEN from ratio of the city's export volumes to its GDP to the export volume; Regression (5) changed the measure of $P G D P$ from GDP per capita to disposable income per capita; Regression (6) changed all the control variables from the former to the letter. From the regressions, even if the measures of control variables are changed from absolute variables to relative variables (or from relative variables to absolute variables), the coefficients of $\mathrm{CO}_{2}$ are still significantly positive, which verifies the robustness of the corresponding conclusion from hypothesis 1 .

According to the descriptive statistics of $Y 02$ and its types, the number of patents in some cities and some years is zero. We eliminated these samples and re-estimated the coefficients to avoid the bias caused by extreme values. Regressions (1) to (8) are reported in columns (1) to (8) in Table 7. Regression (1) reports the results of the benchmark model after excluding the extreme values, and the $\mathrm{CO}_{2}$ coefficient is significantly positive, which verified the robustness of the corresponding conclusions from hypothesis 1 . Regressions (2) to (8) report the regression results of different Y02 types after excluding the extreme values. The $\mathrm{CO}_{2}$ coefficients of all $\mathrm{Y} 02$ types are significantly positive, and the order of these coefficients is consistent with that of the coefficients in Table 3, which verifies the robustness of the corresponding conclusions from hypothesis 2 .

The t-statistic in parenthesis. $* * *, * *$, and $*$ indicate statistically significant at $1 \%, 5 \%$, and $10 \%$, respectively

For mediation models, the same method is used for the robustness analysis. Regressions (1) (4) are reported in columns (3) and (6) of Table 4. By comparing the coefficients of $\mathrm{CO}_{2}$, it is found that hypothesis 3 still holds and the result is robust. Besides, in the robustness test results for the mediation effect, the signs and significance of the coefficients of each control variable are also consistent with previous results and show the conclusions are robust.

\section{Discussion}

Analyzing the benchmark regression results, it is verified that low-carbon innovation can be stimulated by carbon emissions. From the city-level, when carbon emissions increase, lowcarbon innovation rises with it. The conclusion is positive, as low-carbon innovation is of vital importance to achieving
Table 6 Results for robust test on benchmark models with the whole Y02 regressed

\begin{tabular}{lllllll}
\hline & $\underline{(1)}$ & $\underline{(2)}$ & $\underline{(3)}$ & $\underline{(4)}$ & $\underline{(5)}$ & $\underline{(6)}$ \\
\hline \multirow{2}{*}{ Substitution variable } & $\underline{\text { Y02 }}$ & $\underline{\mathrm{Y} 02}$ & $\underline{\mathrm{Y} 02}$ & $\underline{\mathrm{Y} 02}$ & $\underline{\text { Y02 }}$ & $\underline{\underline{Y} 02}$ \\
$\mathrm{CO}_{2}$ & \#RD & \#FDI & \#INT & \#OPEN & \#PGDP & ALL \\
& $4.472^{* * *}$ & $3.376^{* * *}$ & $3.260^{* * *}$ & $2.769^{* * *}$ & $0.739 * * *$ & $1.575^{* * *}$ \\
Other control variables & Yes & Yes & Yes & Yes & Yes & Yes \\
Constant term & Yes & Yes & Yes & Yes & Yes & Yes \\
City effect & Yes & Yes & Yes & Yes & Yes & Yes \\
Year effect & Yes & Yes & Yes & Yes & Yes & Yes \\
Observations & 2262 & 2315 & 2262 & 2262 & 2419 & 2471 \\
\hline
\end{tabular}


Table 7 Results for robust test on benchmark models with different types of Y02 regressed

\begin{tabular}{|c|c|c|c|c|c|c|c|c|}
\hline & $\underline{(1)}$ & $\underline{(2)}$ & $\underline{(3)}$ & $\underline{(4)}$ & $\underline{(5)}$ & $\underline{(6)}$ & $\underline{(7)}$ & $\underline{(8)}$ \\
\hline & Y02 & Y02B & Y02C & Y02D & Y02E & Y02P & Y02T & Y02W \\
\hline \multirow[t]{2}{*}{$\mathrm{CO}_{2}$} & $3.234 * * *$ & $0.273 * * *$ & $0.030 * * *$ & $0.287 * * *$ & $1.155^{* * * *}$ & $1.202 * * *$ & $0.252 * * *$ & $0.255 * * *$ \\
\hline & (14.89) & $(7.48)$ & $(8.02)$ & $(7.42)$ & (12.72) & (14.98) & $(9.41)$ & $(8.02)$ \\
\hline \multirow[t]{2}{*}{$\mathrm{RD}$} & $1.324 * * *$ & $0.135 * * *$ & $0.011 * * *$ & 0.009 & $0.382 * * *$ & $0.466 * * *$ & $0.312 * * *$ & $0.108 * * *$ \\
\hline & $(15.60)$ & $(9.43)$ & $(7.80)$ & $(0.62)$ & (10.77) & (14.86) & $(29.81)$ & (8.67) \\
\hline \multirow[t]{2}{*}{ FDI } & $-2.701 * * *$ & $-0.630 * * *$ & $0.021 * *$ & $-0.417 * * *$ & $-1.096 * * *$ & $-0.747 * * *$ & 0.082 & $-0.232 * * *$ \\
\hline & $(-5.36)$ & $(-7.44)$ & $(2.44)$ & $(-4.64)$ & $(-5.21)$ & $(-4.01)$ & $(1.32)$ & $(-3.14)$ \\
\hline \multirow[t]{2}{*}{ INT } & 0.214 & $0.551 * * *$ & $0.042 * * *$ & -0.102 & -0.129 & 0.104 & -0.118 & -0.058 \\
\hline & $(0.30)$ & $(4.53)$ & (3.39) & $(-0.79)$ & $(-0.43)$ & $(0.39)$ & $(-1.32)$ & $(-0.55)$ \\
\hline \multirow[t]{2}{*}{ OPEN } & $-52.194 * * *$ & $-13.892 * * *$ & -0.144 & $-11.203 * * *$ & $-14.780 * * *$ & $-10.945^{* *}$ & -2.029 & $-4.434 * *$ \\
\hline & $(-3.93)$ & $(-6.22)$ & $(-0.63)$ & $(-4.73)$ & $(-2.66)$ & $(-2.23)$ & $(-1.24)$ & $(-2.28)$ \\
\hline \multirow[t]{2}{*}{ PGDP } & -0.222 & -0.016 & -0.014 & -0.033 & 0.098 & -0.266 & 0.059 & -0.089 \\
\hline & $(-0.35)$ & $(-0.15)$ & $(-1.34)$ & $(-0.30)$ & $(0.38)$ & $(-1.15)$ & $(0.77)$ & $(-0.98)$ \\
\hline Constant term & Yes & Yes & Yes & Yes & Yes & Yes & Yes & Yes \\
\hline City effect & Yes & Yes & Yes & Yes & Yes & Yes & Yes & Yes \\
\hline Year effect & Yes & Yes & Yes & Yes & Yes & Yes & Yes & Yes \\
\hline Observations & 1947 & 1947 & 1947 & 1947 & 1947 & 1947 & 1947 & 1947 \\
\hline
\end{tabular}

net-zero carbon emissions (Deutch 2020); humans' positive response to carbon emissions is conducive to achieving this goal as early as possible (Wang et al. 2020).

Analyzing the regression results of different low-carbon innovation types, we found that though the stimulation varies across low-carbon innovation types, the positive effect always holds. It helps strengthen the above conclusion and demonstrates that the low-carbon innovation driven by carbon emissions is diversified. In terms of low-carbon innovation types, Y02E and Y02P are more affected by carbon emissions than other types. It suggests that when carbon emissions increase, low-carbon innovation will flow to economic activities with more carbon emissions. This means that climate change can contribute to the allocation of innovation resources. For carbon-intensive economic activities, carbon reduction is not always easy (Deutch 2020). With climate change issues becoming more frequent, more attention is paid to high-carbon sectors, making the related low-carbon innovation more promising (Fragkiadakis et al. 2020; Kamat et al. 2020). Government tends to adjust low-carbon policies, such as creating a more suitable environment for low-carbon innovation, providing subsidies for enterprises, or introducing highly educated talents (Price et al. 2016). Some excellent enterprises are making aggressive technological changes to improve financial performance and gain a first-mover advantage in sustainability (Metta et al. 2020).

Analyzing the regression results of the mediating effect model, we find that environmental awareness only plays a partial mediating role between carbon emissions and lowcarbon innovation, which accounts for $25 \%$. It means that low-carbon innovation may be stimulated by other mediation channels, such as environmental regulations (Wang et al. 2020). However, we can also conclude that environmental awareness is a vital mediation channel for carbon emissions to accelerate low-carbon innovation. Through access to information, such as useful government reports, the public understands the seriousness of climate change (Stoddart et al. 2017). Greater environmental awareness can change people's consumption behaviors. And evidence shows that more consumers are beginning to pay attention to carbon labels and energy-saving products (Zu and Zeng 2020). Environmental awareness is also reflected in the grew of people's attention to corporates' emission responsibilities. These changes in consumer behaviors induce companies to develop and produce lower-carbon products. It means that companies need to make low-carbon transformations and adopt cleaner technologies in the production process.

\section{Conclusions and policy implications}

This study uses 285 Chinese prefecture-level cities' dataset from 2005 to 2016 to explore the impact of carbon emissions on low-carbon innovation and the mediating role of environmental awareness. The main research conclusions are as follows: (1) Carbon emissions accelerate the city's low-carbon technological innovation. As the main body of carbon emissions and innovation, cities have responded positively to the increasingly severe climate change. (2) Carbon emissions have different promotion effects on different low-carbon 
innovation types, and related innovation is likely to flow to economic activities with higher carbon emissions. This shows that carbon emissions help allocate low-carbon innovation resources. (3) Environmental awareness plays a partial mediation role in the influence mechanism of carbon emissions on low-carbon innovation. The increasing carbon emissions improve public environmental awareness, motivating the lowcarbon innovation of enterprises.

This study has the following policy implications. First, governments need to realize that while the increasing carbon emissions represent more threat, the positive effect of carbon emissions on low-carbon innovation means mankind also has an opportunity to turn it into a chance for development. In fact, in addition to environmental benefits, low-carbon transition also has obvious economic and social benefits (Sovacool et al. 2020). Governments can use a variety of climate policies to help stimulate the positive impact of carbon emissions on low-carbon innovation, for example, by using policy instruments such as tax incentives or government procurement to support low-carbon innovation in higher carbon emissions sectors (e.g., industrial production and energy).

Second, the cultivation of public environmental awareness should be accelerated. What needs to be concerned about is that although low-carbon development depends on govern- ment regulation and guidance to the industry, it needs to rely on market forces to make consumers voluntarily pay for lowcarbon products. The improvement of environmental awareness is conducive to consumers' environmentally friendly purchasing behavior (Sharma et al. 2020) and stimulates enterprises to carry out low-carbon innovation (He et al. 2019). In turn, this innovation can further improve the user experience of low-carbon products and attract more consumers, thus forming a virtuous cycle. While many countries are starting to make consuming products provide their carbon emissions data or carbon footprint labels, this is not enough. Media, governments, and enterprises should give more detailed explanations behind them, as it is difficult for people to respond to the information they do not understand (Testa et al. 2020).

Finally, due to the importance of low-carbon technologies in achieving carbon neutrality, the period from now on to the peak carbon dioxide emissions is critical for countries to accumulate low-carbon technologies. At this period, the lowcarbon technologies' development can benefit from the "dividend" of the increased carbon emissions, which may no longer exist after the peak has been reached. Accumulating more breakthrough low-carbon technologies in this phase will reduce the time needed to move from peak carbon dioxide emissions to carbon neutrality.

\section{Appendix A}

Table 8 The subclasses in the Y02 scheme

\section{Scheme Description}

Y02 Technologies or applications for mitigation or adaptation against climate change

Y02A Technologies for adaptation to climate change

Y02B Climate change mitigation technologies related to buildings, e.g., housing, house appliances, or related end-user applications

Y02C Capture, storage, sequestration, or disposal of GHG

Y02D Climate change mitigation technologies in information and communication technologies (ICT), i.e., information and communication technologies aiming at the reduction of their own energy use

Y02E Reduction of GHG emissions, related to energy generation, transmission, or distribution

Y02P Climate change mitigation technologies in the production or processing of goods

Y02T Climate change mitigation technologies related to transportation

Y02W Climate change mitigation technologies related to wastewater treatment or waste management 
Table 9 Emission factors of 28 energy sources

\begin{tabular}{|c|c|c|c|}
\hline Fossil fuels & Average low calorific value $(\mathrm{kJ} / \mathrm{kg})$ & $\begin{array}{l}\text { Carbon emission factor }(\mathrm{EF}) \text { - carbon content } \\
\text { per unit calorific value } \\
(\mathrm{TC} / \mathrm{TJ})\end{array}$ & Carbon oxidation rate \\
\hline Row coal & 20,908 & 25.8 & 0.99 \\
\hline Washed coal & 26,344 & 25.8 & 0.99 \\
\hline Other washed coal & 8363 & 25.8 & 0.99 \\
\hline Briquette & 26,344 & 33.6 & 0.90 \\
\hline Coal gangue & 8363 & 25.8 & 1.00 \\
\hline Coke & 28,435 & 29.5 & 0.93 \\
\hline Coke oven gas & 17,354 & 12.1 & 1.00 \\
\hline Blast furnace gas & 3763 & 70.8 & 1.00 \\
\hline Converter gas & 7945 & 49.6 & 1.00 \\
\hline Other gas & 18,274 & 12.1 & 1.00 \\
\hline Other coking products & 33,453 & 29.5 & 0.93 \\
\hline Crude oil & 41,816 & 20.1 & 0.98 \\
\hline Gasoline & 43,070 & 18.9 & 0.98 \\
\hline Kerosene & 43,070 & 19.6 & 0.98 \\
\hline Diesel oil & 42,652 & 20.2 & 0.98 \\
\hline Fuel oil & 41,816 & 21.1 & 0.98 \\
\hline Naphtha & 43,907 & 20.0 & 0.98 \\
\hline Lubricating Oil & 41,398 & 20.0 & 0.98 \\
\hline Paraffin & 39,934 & 20.0 & 1.00 \\
\hline Solvent naphtha & 42,945 & 20.0 & 1.00 \\
\hline Petroleum asphalt & 38,930 & 21.5 & 1.00 \\
\hline Petroleum coke & 31,947 & 27.5 & 0.98 \\
\hline Liquefied petroleum gas & 50,179 & 17.2 & 0.98 \\
\hline Refinery dry gas & 45,998 & 18.2 & 0.98 \\
\hline Other oil products & 41,816 & 20.0 & 0.98 \\
\hline Natural gas & 35,585 & 15.3 & 0.99 \\
\hline Liquefied Natural gas & 51,434 & 17.2 & 0.98 \\
\hline Other energy forms & 29,271 & 12.2 & 0.94 \\
\hline
\end{tabular}

Availability of data and materials Not applicable.

Author contribution An Pan: conceptualization, methodology, funding acquisition, and writing - review and editing

Wenna Zhang: formal analysis and methodology

Qizhuo Xie: writing (original draft) and writing (review and editing)

Ling Dai: software and resources

Yunyi Zhang: data curation and visualization

Funding Financial supports are from the Chinese National Research of Social Sciences Youth funded projects (19CGJ041) and the Fundamental Research Funds for the Central Universities of Zhongnan University of Economics and Law (2722021BZ010, 202110324).

\section{Declarations}

Ethics approval and consent to participate Not applicable.

Consent for publication Not applicable.
Competing interests The authors declare no competing interests.

\section{References}

Akhtar R, Sultana S, Masud MM, Jafrin N, Al-Mamun A (2020) Consumers' environmental ethics, willingness, and green consumerism between lower and higher income groups. Resour Conserv Recycl 168:105274. https://doi.org/10.1016/j.resconrec.2020. 105274

Albino V, Ardito L, Dangelico RM, Petruzzelli AM (2014) Understanding the development trends of low-carbon energy technologies: a patent analysis. Appl Energy 135:836-854

Baron RM, David AK (1986) The moderator-mediator variable distinction in social psychological research: conceptual, strategic, and statistical considerations. J Pers Soc Psychol 51(6):1173-1182

Bastin JF, Clark ER, Elliott T, Hart S, van den Hoogen J, Hordijk I, Ma H, Majumder S, Manoli G, Maschler J, Mo L, Routh D, Yu K, Zohner CM, Crowther TW (2019) Understanding climate change from a 
global analysis of city analogues. PLoS One 14(7):e0217592. https://doi.org/10.1371/journal.pone.0217592

Batool R, Sharif A, Islam T, Zaman K, Shoukry AM, Sharkawy MA, Gani S, Aamir A, Hishan SS (2019) Green is clean: the role of ICT in resource management. Environ Sci Pollut Res 26(24):2534125358

Chang CH (2011) The influence of corporate environmental ethics on competitive advantage: the mediation role of green innovation. $\mathrm{J}$ Bus Ethics 104(3):361-370

Chen Q, Wang Y, Zhang J, Wang Z (2020) The knowledge mapping of concentrating solar power development based on literature analysis technology. Energies 13(8):1988

Deloitte (2018) Global renewable energy trends: solar and wind move from mainstream to preferred. https://www2.deloitte.com/global/en/ pages/energy-and-resources/articles/global-renewable-energytrends.html. Accessed 13 Sept 2018

Deutch J (2020) Is net zero carbon 2050 possible. Joule 4(11):2237-2240

Dhakal S (2009) Urban energy use and carbon emissions from cities in China and policy implications. Energy Policy 37(11):4208-4219

Du Y, Li Z, Du J, Li N, Yan B (2019) Public environmental appeal and innovation of heavy-polluting enterprises. J Clean Prod 222:10091022

Esso LJ, Keho Y (2016) Energy consumption, economic growth and carbon emissions: cointegration and causality evidence from selected African countries. Energy 114:492-497

Fragkiadakis K, Fragkos P, Paroussos L (2020) Low-carbon R\&D can boost EU growth and competitiveness. Energies 13(19):5236

Gosens J (2020) The greening of South-South trade: levels, growth, and specialization of trade in clean energy technologies between countries in the global South. Renew Energy 160:931-943

Hasan MMF, First EL, Boukouvala F, Floudas CA (2015) A multi-scale framework for $\mathrm{CO}_{2}$ capture, utilization, and sequestration: CCUS and CCU. Comput Chem Eng 81:2-21

Haščič I, Migotto M (2015) Measuring environmental innovation using patent data. OECD Environment Working Papers

Hauer ME, Evans JM, Mishra DR (2016) Millions projected to be at risk from sea-level rise in the continental United States. Nat Clim Chang 6(7):691-695

He J, Lei Y, Fu X (2019) Do Consumer's green preference and the reference price effect improve green innovation? A theoretical model using the food supply chain as a case. Int J Environ Res Public Health 16(24):5007

Huo T, Li X, Cai W, Zuo J, Jia F, Wei H (2020) Exploring the impact of urbanization on urban building carbon emissions in China: evidence from a provincial panel data model. Sustain Cities Soc 56:102068. https://doi.org/10.1016/j.scs.2020.102068

IPCC (2019) Choices made now are critical for the future of our ocean and cryosphere. https://www.ipcc.ch/2019/09/25/srocc-pressrelease/. Accessed 25 Sept 2019

Jenkins KE, Hopkins D (2019) Transitions in energy efficiency and demand: the emergence, diffusion and impact of low-carbon innovation, first edn. Routledge, New York

Kajaste R, Hurme M (2016) Cement industry greenhouse gas emissions management options and abatement cost. J Clean Prod 112(5): $4041-4052$

Kamat AS, Khosla R, Narayanamurti V (2020) Illuminating homes with LEDs in India: rapid market creation towards low-carbon technology transition in a developing country. Energy Res Soc Sci 66: 101488. https://doi.org/10.1016/j.erss.2020.101488

Karoline SR, Florian K, Michael H (2017) Conceptual and empirical advances in analysing policy mixes for energy transitions. Energy Res Soc Sci 33:1-10

Le Quéré C, Jackson RB, Jones MW et al (2020) Temporary reduction in daily global $\mathrm{CO}_{2}$ emissions during the COVID-19 forced confinement. Nat Clim Chang 10(7):647-653
Leonidou CN, Leonidou LC (2011) Research into environmental marketing/management: a bibliographic analysis. Eur J Mark 45(1-2):68103

Lin B, Zhu J (2019) Determinants of renewable energy technological innovation in China under $\mathrm{CO}_{2}$ emissions constraint. J Environ Manag 247:662-671

Liu H, Liang X (2011) Strategy for promoting low-carbon technology transfer to developing countries: the case of CCS. Energy Policy 39(6):3106-3116

Liu P, Teng M, Han C (2020) How does environmental knowledge translate into pro-environmental behaviors? The mediating role of environmental attitudes and behavioral intentions. Sci Total Environ 728:138126. https://doi.org/10.1016/j.scitotenv.2020.138126

Lo K (2014) China's low-carbon city initiatives: the implementation gap and the limits of the target responsibility system. Habitat Int 42:236244

Loureiro ML, Lotade J (2005) Do fair trade and eco-labels in coffee wake up the consumer conscience? Ecol Econ 53(1):129-138

Luo Y, Salman M, Lu Z (2020) Heterogeneous impacts of environmental regulations and foreign direct investment on green innovation across different regions in China. Sci Total Environ 759:143744. https:// doi.org/10.1016/j.scitotenv.2020.143744

Malhotra A, Schmidt TS (2020) Accelerating low-carbon innovation. Joule 4(11):2259-2267

Mastrotheodoros T, Pappas C, Molnar P, Burlando P, Manoli G, Parajka J, Rigon R, Szeles B, Bottazzi M, Hadjidoukas P, Fatichi S (2020) More green and less blue water in the Alps during warmer summers. Nat Clim Chang 10(2):155-161

Mennicken L, Janz A, Roth S (2016) The German R\&D program for $\mathrm{CO}_{2}$ utilization - innovations for a green economy. Environ Sci Pollut Res 23(11):11386-11392

Metta J, An Y, Zheng H, Zhang L (2020) Potentials and opportunities towards the low carbon technologies - from literature review to new classification. Crit Rev Environ Sci Technol 50(10):1013-1042

Mohanty LK, Maiti S (2021) Regional morphodynamics of supraglacial lakes in the Everest Himalaya. Sci Total Environ 751:141586. https://doi.org/10.1016/j.scitotenv.2020.141586

Motoshita M, Sakagami M, Kudoh Y, Tahara K, Inaba A (2015) Potential impacts of information disclosure designed to motivate Japanese consumers to reduce carbon dioxide emissions on choice of shopping method for daily foods and drinks. J Clean Prod 101:205-214

Murray AG, Mills BF (2011) Read the label! Energy Star appliance label awareness and uptake among US consumers. Energy Econ 33(6): $1103-1110$

Ohler AM, Loomis DG, Ilves K (2020) A study of electricity savings from energy star appliances using household survey data. Energy Policy 144:111607. https://doi.org/10.1016/j.enpol.2020.111607

Paramati SR, Alam S, Hammoudeh S, Hafeez K (2020) Long-run relationship between R\&D investment and environmental sustainability: evidence from the European Union member countries. Int $\mathrm{J}$ Financ Econ. https://doi.org/10.1002/ijfe.2093

Polzin F (2017) Mobilizing private finance for low-carbon innovation-a systematic review of barriers and solutions. Renew Sust Energ Rev 77:525-535

Price L, Zhou N, Fridley D et al (2016) Low-Carbon City Policy Databook: 72 Policy recommendations for Chinese cities from the benchmarking and energy savings tool for low carbon cities. https:// doi.org/10.2172/1345201.

Rahman ZU, Khattak SI, Ahmad M, Khan A (2020) A disaggregatedlevel analysis of the relationship among energy production, energy consumption and economic growth: evidence from China. Energy 194:116836. https://doi.org/10.1016/j.energy.2019.116836

Rogge KS, Schleich J (2018) Do policy mix characteristics matter for low-carbon innovation? A survey-based exploration of renewable power generation technologies in Germany. Res Policy 47(9):1639_ 1654 
Sarfraz M, He B, Shah SGM (2020) Elucidating the effectiveness of cognitive $\mathrm{CEO}$ on corporate environmental performance: the mediating role of corporate innovation. Environ Sci Pollut Res 27(36): 45938-45948

Sharma N, Saha R, Sreedharan VR, Paul J (2020) Relating the role of green self-concepts and identity on green purchasing behaviour: an empirical analysis. Bus Strateg Environ 29(8):3203-3219

Shi L, Liu J, Wang Y, Chiu A (2021) Cleaner production progress in developing and transition countries. J Clean Prod 278:123763. https://doi.org/10.1016/j.jclepro.2020.12

Sieg T, Schinko T, Vogel K, Mechler R, Merz B, Kreibich H (2019) Integrated assessment of short-term direct and indirect economic flood impacts including uncertainty quantification. PLoS One 14(4):e0212932. https://doi.org/10.1371/journal.pone.0212932

Song Q, Qin M, Wang R, Qi Y (2020) How does the nested structure affect policy innovation?: Empirical research on China's low carbon pilot cities. Energy Policy 144:111695. https://doi.org/10.1016/j. enpol.2020.111695

Sovacool BK, Martiskainen M, Hook A, Baker L (2020) Beyond cost and carbon: the multidimensional co-benefits of low carbon transitions in Europe. Ecol Econ 169:106529. https://doi.org/10.1016/j. ecolecon.2019.106529

Soytas U, Sari R (2009) Energy consumption, economic growth, and carbon emissions: challenges faced by an EU candidate member. Ecol Econ 68(6):1667-1675

Stoddart MCJ, Ylä-Anttila T, Tindall DB (2017) Media, politics, and climate change: the ASA Task Force report and beyond. Environ Sociol 3(4):309-320

Su HN, Moaniba IM (2017) Does innovation respond to climate change? Empirical evidence from patents and greenhouse gas emissions. Technol Forecast Soc Chang 122:49-62

Testa F, Iovino R, Iraldo F (2020) The circular economy and consumer behaviour: the mediating role of information seeking in buying circular packaging. Bus Strateg Environ 29(8):3435-3448

UNEP (2020) Emissions Gap Report 2020: an inflection point. https:// www.unep.org/news-and-stories/video/emissions-gap-report-2020inflection-point. Accessed 9 Dec 2020

Vallance P, Tewdwr-Jones M, Kempton L (2020) Building collaborative platforms for urban innovation: Newcastle City Futures as a quadruple helix intermediary. Eur Urban Reg Stud 27(4):325-341
Von Hirschhausen C, Herold J, Oei PY (2012) How a "low carbon" innovation can fail - tales from a "lost decade" for carbon capture, transport, and sequestration (CCTS). Econ Energy Environ Policy 1(2): $115-124$

Wang W, Lu N, Zhang C (2018) Low- carbon technology innovation responding to climate change based on perspective of spatial spillover effect. China Populat, Resour Environ 28(8):22-30

Wang W, Li Y, Lu N, Wang D, Jiang H, Zhang C (2020) Does increasing carbon emissions lead to accelerated eco-innovation? Empirical evidence from China. J Clean Prod 251:119690. https://doi.org/10. 1016/j.jclepro.2019.119690

Wilson C (2018) Disruptive low-carbon innovation. Energy Res Soc Sci 37:216-223

Wilson C, Pettifor H, Cassar E, Kerr L, Wilson M (2019) The potential contribution of disruptive low-carbon innovation to $1.5^{\circ} \mathrm{C}$ climate mitigation. Energy Effic 12(2):423-440

WIPO (2020) Patenting trends in renewable energy. https://www.wipo. int/wipo_magazine/en/2020/01/article_0008.html. Accessed 30 March 2020

Xu X, Watts A, Reed M (2019) Does access to Internet promote innovation? A look at the US broadband industry. Growth Chang 50(4): $1423-1440$

Yang C, Liu S (2020) Spatial correlation analysis of low-carbon innovation: a case study of manufacturing patents in China. J Clean Prod 273:122893. https://doi.org/10.1016/j.jclepro.2020.122893

Zhang YJ, Peng YL, Ma CQ, Shen B (2017) Can environmental innovation facilitate carbon emissions reduction? Evidence from China. Energy Policy 100:18-28

Zhang W, Villarini G, Vecchi GA, Smith JA (2018) Urbanization exacerbated the rainfall and flooding caused by hurricane Harvey in Houston. Nature 563(7731):384-388

$\mathrm{Zu} \mathrm{Y,} \mathrm{Zeng} \mathrm{X} \mathrm{(2020)} \mathrm{Research} \mathrm{on} \mathrm{energy} \mathrm{efficiency} \mathrm{improvement} \mathrm{in} \mathrm{a}$ supply chain with discontinuous market demand. Environ Sci Pollut Res 27(13):15537-15551

Publisher's note Springer Nature remains neutral with regard to jurisdictional claims in published maps and institutional affiliations. 